\title{
MATCHING ACCOUNTABILITY WITH INDEPENDENCE: THE ECB'S EXPERIENCE
}

\author{
by Alessandro Giovannini and Jean-François Jamet
}

\section{Introduction}

In fighting the Great Recession, central banks of advanced economies have played a decisive role, going beyond their standard toolkit. And they have been subject to equally strong attention and scrutiny, facing at the same time considerable expectations and increased controversy. In this context the importance of accountability came to the fore.

The European Central Bank (ECB) was no exception. The ECB implemented similar monetary policy measures to those of the other major central banks around the world. These included asset purchases (like in the United States, Japan and the United Kingdom) and negative interest rates (like in Sweden and Switzerland) ${ }^{1}$.

The ECB's role, however, was perhaps even more essential than elsewhere. Not only was the ECB facing risks of deflation, soaring unemployment and a double-dip recession in the euro area, but it also faced increasing 'redenomination' risk premia against the background of the sovereign debt overhang in several countries. In other words, it was not only price stability that was at stake, but also the integrity of the

European Central Bank.

* The views expressed in this article are solely those of the authors and do not necessarily reflect those of the European Central Bank (ЕCB). This article should thus not be reported as representing the views of the ECB.

1 For a comparison of the different policy response in the US and in the euro area during the financial crisis, see D. Gros, C. Alcidi, and A. Giovannini, Central Banks in Times of Crisis: The FED vs. the ECB', CEPS Policy Brief, No. 276. 
single currency. It is against this background that in July 2012 ECB President Draghi said: "Within our mandate, the ECB is ready to do whatever it takes to preserve the euro" 2 .

In addition to the economic challenges arising from the zero nominal lower bound, the ЕСв had to operate in a sui generis institutional environment, with no government at euro area level as a counterpart but imperfect coordination of fiscal, economic and financial policies by euro area Member States. Going into the crisis, the euro area also did not have crisis management capacities, its monitoring of macroeconomic imbalances was deficient, it did not have a single financial rulebook or common financial watchdogs, and there was no solid fiscal or financial union: fiscal buffers were insufficient in several countries, there was no common budget to provide automatic stabilisers at euro area level and financial risk-sharing was essentially limited to crossborder lending flows among banks, which stopped or even reversed when the crisis started. In this context, fragile economies had to adopt fiscal and financial consolidation policies that had a procyclical impact. Economic performance diverged, financial markets fragmented, and fiscal policy tightened in $2011^{3}$.

Against this background, the ECB took resolute action within its mandate. To stabilise prices, the ECB resorted to unconventional monetary policies, bringing the deposit facility rate into negative territory and launching a large-scale asset purchase programme ${ }^{4}$. As a result, the ECB's balance sheet more than tripled in size. Lending its credibility, the ECB also took on new tasks, becoming a pillar of the new supervisory architecture as a euro area wide micro- and macro-prudential supervisor. As a result, the ECB's headcount doubled when compared to the previous ten years. Finally, the ECB was called upon to provide its financial expertise in financial assistance programme, becoming a member of the so-called "Troika". Therefore, the scope of the ECB's

2 M. DRAGHI, Verbatim of the remarks made by Mario Draghi. 26 July 2012, Global Investment Conference, London. Available at: https://www.ecb.europa.eu/press/key/date/ 2012/html/sp120726.en.html

3 ECB, The euro area fiscal stance, in "ECB Economic Bulletin”, n. 4, 2016, pp. 68-87.

$4 \mathrm{ECB}$, The use of the Eurosystem's monetary policy instruments and operational framework since 2012', ЕСВ Occasional paper no. 188, May 2017. 
task and its responsibility as an institution of a federal nature in a still incomplete EMU significantly increased. And this came simultaneously with the further enlargement of the euro area: since 2007, seven member states joined.

With such an important role, it is not surprising that the ECB has been exposed to increased attention and the subject of intense debate. Similar to other institutions at European but also national level, it faced decreasing trust from euro area citizens confronted with the economic and social impact of the crisis 5 . Many questioned whether its measures where appropriate and effective, with some even arguing that the ECB was overstepping its mandate.

This rise in the public prominence of the ЕСB and in the criticism of the ECB's actions had to face the peculiar institutional set-up of the ECB. Contrary to political institutions, the ECB is independent from political influence: it is protected from any interference likely to hinder the attainment of its objective. Strong accountability is the necessary counterpart to independence in ensuring the legitimacy of the ECB's action. While this was the case also before the crisis, accountability assumed increased prominence in times where the ECB's output legitimacy was being questioned.

According to the Cambridge English Dictionary, accountability means "a situation in which someone is responsible for things that happen and can give a satisfactory reason for them". Applied to the ECB, this means that the ЕCB is accountable for delivering on its mandate. Accountability is thus here understood as the legal and political obligation of the ЕCB to justify and explain its decisions to the citizens and their elected representatives ${ }^{6}$. Similarly to other central banks, the ECB was given a democratic mandate prioritising price stability 7 . Contrary to other central banks, however, this mandate and the central bank's statute are enshrined in primary rather than secondary law, providing

5 M. Berlemann, Trust in the European Central Bank throughout the world-wide financial crisis and European debt crisi, in D. Maltritz, M. Berlemann (eds.) "Financial Crises, Sovereign Risk and the Role of Institutions", London, Springer, pp. 25-48.

$6 \mathrm{ECB}$, The accountability of the $E C B$, in "ЕCB Monthly Bulletin", November 2002, pp. $45-57$.

7 M. Georgsson, A. VRedin, P.Å. Sommar, The modern central bank's mandate and the discussion following the financial crisis in "Sveriges Riksbank Economic Review", n. 1, 2015, pp. 7-42. 
it additional strength. The fact that these three essential ingredients for the ECB's activity (mandate, independence and accountability) are all enshrined in primary law should not come as surprise, given their interrelation. Independence ensures that the ECB can act in line with its democratic mandate, being protected from political influence or shortsighted pressure of any form. Accountability, on the other hand, ensures that the ECB does act in accordance with its mandate.

The ECB's accountability therefore encompasses the various channels through which the ECB is asked to demonstrate that it is acting in accordance with its mandate. This article focuses mainly on one of these channels - democratic accountability -, while other articles of this publication provide insights into other channels such as judicial accountability and the ECB's communication. It is however important to keep in mind that these various channels reinforce each other. Moreover, in discussing the ECB's accountability framework, the primary focus is placed on the central banking, rather than supervisory, functions.

The article is organised as follows. Section 1 discusses the necessary balance between the ECB's independence and accountability and explains the ECB's accountability framework Section 2 discusses the ECB's accountability from a political economy perspective. Section 3 explains how, within the framework defined by the Treaty, the ЕСB accountability has evolved in practice during the crisis to allow enhanced scrutiny.

\section{Balancing independence and accountability: a legal and institutional perspective}

Since one of the cornerstones of euro area monetary policy is the independence of the ECB (and National Central Banks composing the Eurosystem) from political influence, it is hard to disentangle it from any debate on the ECB's accountability.

The importance of central bank independence is a relatively recent phenomenon, if considered with the eyes of an historian. Rogoff 8 was among the first to theorize the importance of appointing a "conserva-

8 K. Rogoff, The optimal degree of commitment to an intermediate monetary target, in "The Quarterly Journal of Economics", n. 4, 1985, pp. 1169-1189. 
tive" central banker as a remedy to inflationary public spending. This view was gradually underpinned by extensive empirical evidence and theoretical analyses showing that independent central banks are better capable of maintaining low inflation rates 9 . This literature has influenced the institutional design of the ECB.

The need for protecting the ECB from any interference likely to hinder the attainment of this objective found its way into the Treaty on the Functioning of the EU (TFEU) and in a Treaty Protocol on the Statute of the European System of Central Banks and of the $\mathrm{ECB}^{10}$. While the independence of many central banks around the world may be amended by more or less complex legislative procedures, the independence of the ЕСв has been enshrined in the Treaties, the amendment of which requires a complex and very politically expensive decision-making process ${ }^{11}$.

Accountability is the necessary counterpart to the ECB's independence. While independence ensures that the $\mathrm{ECB}$ can act in accordance with its mandate, accountability allows to verify that the ECB does indeed act in accordance with its mandate. Therefore, independence and accountability go hand in hand: accountability balances independence, ensuring that independence does not mean arbitrariness.

9 A. Cukierman, Central bank independence and monetary policymaking institutions - Past, present and future, in "European Journal of Political Economy", n. 4, 2008, pp. 722-736.

${ }^{10}$ In particular Article 130 TFEU contains two provisions: one for the ECB, the NCBS and the members of their decision-making bodies who shall not seek or take instructions from Union institutions, bodies, offices or agencies, from any government of a Member State or from any other body; the second one, instead, is for the Union institutions, bodies, offices or agencies and the governments of the Member States who shall undertake to respect this principle and not to seek to influence the members of the decision-making bodies of the above-mentioned institutions when they perform their tasks. The concept of independence applicable to the ECB includes: institutional independence, legal independence, personal independence of the members of its decision-making bodies, functional and operational independence and financial and organisational independence. For a discussion of these aspects, see H. K. Scheller, The European Central Bank: History, Role and Functions, European Central Bank. Available at: https://www.ecb.europa.eu/pub/pdf/other/ecbhistoryrolefunctions2006en.pdf

${ }^{11}$ It should be noted that for national central banks to become an integral part of the ESCB, Member States have to ensure that national legislation is compatible with the Treaty and the Statute of the ESCB. This obligation of legal convergence aims at removing inconsistencies in respect of features such as institutional, personal, functional and financial independence. 
Together, independence and accountability thus support simultaneously effectiveness and legitimacy. They ensure that the ECB is not only in theory but also in practice bound by its democratic mandate, while being protected from external pressures that may be short-sighted or motivated by other considerations than achieving the ECB's mandate.

EU primary law foresees explicit accountability obligations. From a legal review perspective, the ECB's decisions can be challenged at the Court of Justice of the EU. From a democratic perspective, the EU Treaties and the ECB Statute ${ }^{12}$ provide that the ECB is primarily accountable to the European Parliament as the representation of EU citizens ${ }^{13}$. It also has to report regularly to the Council of the EU which represents Member State governments ${ }^{14}$. The conciseness of the Treaties' provisions regarding the ECB's accountability have also not prevented the establishment of accountability practices that extend beyond the mere letter of the Treaties but are fully consistent with it and with its spirit.

In line with Article 284(3), the ECB submits an annual report on its tasks, the activities of the ESCB and the Eurosystem's monetary policy to the European Parliament, the Council of the EU, the European Commission and the European Council. The report is presented each year to the European Parliament by the Vice-President of the ECB in a dedicated session of the Committee on Economic and Monetary Affairs and by the President on the occasion of a plenary debate. In the European Parliament's practice, the debate is generally concluded with the adoption of a Resolution summarising the European Parliament's view on the ECB policy and practices. The following year, when submitting

12 Article 15(3) of the Statute of the European System of Central Banks and the European Central Bank.

13 The ЕСB is not accountable to national parliaments as its objective is for the euro area as a whole. However, the ECB has engaged in exchanges of views with national parliaments, as they constitute important fora at national level where the ECB can explain its decisions.

${ }^{14}$ Specifically, Article 284(3) TFEU reads: "The European Central Bank shall address an annual report on the activities of the ESCB and on the monetary policy of both the previous and current year to the European Parliament, the Council and the Commission, and also to the European Council. The President of the European Central Bank shall present this report to the Council and to the European Parliament, which may hold a general debate on that basis. The President of the European Central Bank and the other members of the Executive Board may, at the request of the European Parliament or on their own initiative, be heard by the competent committees of the European Parliament." 
its annual report to the European Parliament, the ECB also publishes its feedback on the input provided by the European Parliament as part of its resolution on the previous annual report. In line with a request of the European Parliament, this feedback is also published on the ECB's website and contains a detailed discussion of the various issues raised in the resolution ${ }^{15}$.

Since its inception, the cornerstone of the accountability framework has become the so called "Monetary Dialogue", i.e. the ECB's President's participation in the regular quarterly hearings of the Committee on Economic and Monetary Affairs of the European Parliament. Article 126 of the Rules of Procedure of the European Parliament foresees the invitation of the President of the ECB "to make a statement and answer questions" in the Committee at least four times a year. It also foresees that the transcript of each of these hearings shall be drawn up. The Monetary Dialogue represents the main instrument through which the EP holds the ECB to account ${ }^{16}$. The importance of this event was also clearly expressed by the ЕСв President Mario Draghi in September 2016, when he said that he drew substantial and substantive benefits from the regular hearings, that they are one of the contributors to the ECB's monetary policy decisions and that they are taken very seriously. The importance of such hearings was also recognised early by the European Parliament itself: in the second parliamentary resolution on the ECB Annual Report argued that the monetary dialogue had developed into one of the cornerstones of the ECB's accountability and thus provides a democratic guarantee of the Bank's independence ${ }^{17}$.

The quarterly hearings and the presence in the EP linked to the presentation and discussion of the Annual Report do not exhaust the interactions between the two institutions. Other Executive Board members also participate in hearings of the Committee on Economic and Mon-

15 The 2016 Feedback on the input provided by the European Parliament can for instance be accessed at https://www.ecb.europa.eu/pub/pdf/other/20160407_feedback_on_ the_input_provided_by_the_european_parliament_en.pdf.

16 See the Transcript of the hearing of ECB President in the ECON Committee on 26 September 2016 available on the European Parliament website at http://www.europarl.europa.eu/cmsdata/108092/Monetary_dialogue_26092016_EN.pdf

17 See. European Parliament resolution on the 1999 Annual Report of the European Central Bank, Strasbourg, European Parliament. Retrieved from http://www.europarl.europa.eu/sides/getDoc.do?pubRef=-\%2f\%2fEP $\% 2 f \% 2$ fTEXT $\% 2$ bTA $\% 2 b P 5-T A-2000$ - 
etary Affairs - but occasionally also interactions with other Committees - to explain the ECB's reasoning and decisions on specific topics. Finally, according to Rule 131 of the Rule of Procedures of the European Parliament, Members of the European Parliament can address written questions to the ЕСВ. The replies to these questions are published on the two institutions' websites ${ }^{18}$.

The definition of parliamentary scrutiny procedures on the monetary policy of the ECB was in part influenced by US experience. Based on the 1978 Full Employment and Balanced Growth Act (the HumphreyHawkins Act), the FED is required to submit to the Congress a sixmonthly statement containing an analysis of economic and financial developments as well as economic and monetary policy projections. The report is examined by the relevant parliamentary committees (the Committee on Financial Services - also known as House Banking Committee - at the House of Representatives and the Committee on Banking, Housing and Urban Affairs at the Senate). Similarly to the ECB's meetings in the European Parliament, the FED Chairman's hearings before commissions are also broadcasted and also other Federal Reserve officials often testify before the Congress ${ }^{19}$. The ability of the Congress procedures to hold sufficiently accountable the FED for its monetary policy decisions has given rise to discussions on the other side of the Atlantic ${ }^{20}$. These discussions are not so different from those that took place in Europe. While in a first phase the debate had focused more on the areas not covered by the Treaty ${ }^{21}$, it later looked more extensively at the quality of the

${ }^{18}$ In addition, these occasions, the European Parliament's involvement is also foreseen in the process for the appointment of members of the Executive Board of the ECB, including the President and the Vice President. According to Article 283, par. 2 TFEU, the members of the Executive Board are appointed by the Council, acting by a qualified majority on a recommendation from the Council and after consulting the European Parliament. According to Article 122 of the EP Rules of Procedure, the proposed candidate is invited to make a statement before the Competent Committee and to answer the questions raised by Members.

${ }^{19}$ For a discussion on the FED's accountability framework see I.L. MORRIS, Congress, the President, and the Federal Reserve: The politics of American monetary policy-making, Ann Arbor, University of Michigan Press, 2000.

20 See inter alia J.L. PIERCE, The myth of congressional supervision of monetary policy in "Journal of Monetary Economics", n. 2, 1978, pp. 363-370 and R.E. WAGNER, Central banking and the Fed: a public choice perspective, in "Cato Journal", n. 6, 1986, pp. 519-543.

21 P.L. LINDSETH, Democratic legitimacy and the administrative character of supra- 
interaction between the ECB and the European Parliament ${ }^{22}$. Considering results from five different studies ${ }^{23}$ argued that $\mathrm{ECB}$ did not performs very differently from the FED.

The ECB's accountability practices have therefore developed over the years beyond the mere Treaty requirements, as part of healthy interinstitutional relations and using the possibilities opened by the Treaties. The evolution of the accountability channels has therefore invalidated earlier concerns that the Treaties might allow "for no clear accountability to any other arm of national or European government"24. Similarly, the Treaties' provisions allowed for a specific regime to be set down regarding the ECB's accountability for its banking supervision tasks ${ }^{25}$ as part of the Single Supervisory Mechanism (SSM) Regulation ${ }^{26}$. The practical fulfilment of supervisory accountability requirements are further clarified in an Interinstitutional Agreement between the European Parliament and the $\mathrm{ECB}^{27}$, as well as a Memorandum of Understanding between the Council of the $\mathrm{EU}$ and the $\mathrm{ECB}^{28}$.

nationalism: the example of the European Community in "Columbia Law Review", n.3, 1999, pp. 628-738.

22 C. Wyplosz, S. Nickell, M. Wolf, European Monetary Union: The Dark Sides of a Major Success, in "Economic Policy", 21(46), 2006, pp. 207-261; S. Collignon, S. DIESSNER, The ECB's Monetary Dialogue with the European Parliament: Efficiency and Accountability during the Euro Crisis?, in "Journal of Common Market Studies", n. 6, 2016, pp. 1-17.

23 P. De Grauwe, D. Gros, Accountability and Transparency in Central Banking'. Study for the European Parliament's Committee on Economic and Monetary Affairs,2009 available at http://www.europarl.europa.eu/RegData/etudes/etudes/join/2009/416220/ IPOL-ECON_ET(2009)416220_EN.pdf

${ }^{24}$ See Europe's New Currency: Gambling on the Euro, in "The Economist", January 2, 1999, p. 2.

25 The ECB's accountability framework for supervisory tasks is presented on a dedicated section of the ЕСВ Banking Supervision website, which can be accessed at: https://www.bankingsupervision.europa.eu/organisation/accountability/html/index.en.html

${ }^{26}$ Council Regulation (EU) No 1024/2013 of 15 October 2013 conferring specific tasks on the European Central Bank concerning policies relating to the prudential supervision of credit institutions. OJ L 287, 29.10.2013, p. 63-89.

27 Interinstitutional Agreement between the European Parliament and the European Central Bank on the practical modalities of the exercise of democratic accountability and oversight over the exercise of the tasks conferred on the ECB within the framework of the Single Supervisory Mechanism (2013/694/EU), OJ L 320, 30.11.2013.

${ }^{28}$ Memorandum of Understanding between the Council of the European Union and the European Central Bank on the cooperation on procedures related to the Single Super- 
An essential complement of accountability is transparency. Building on the Treaty's requirements and going further, the ЕСB has developed over the years various channels of communication to make its decisions transparent to the European public. The ECB's interactions in the European Parliament are livestreamed and recorded. In addition, the ECB holds press conferences after each Governing Council monetary policy meeting setting key interest rates for the euro area, i.e. every six weeks. Moreover, the accounts of the Governing Council's discussions are published four weeks after each monetary policy meeting. Another important communication channel is represented by the frequent articles, interviews and speeches of members of the Executive Board. These are published on the ECB's website. The Economic Bulletin (formerly Monthly Bulletin) also presents the economic and monetary information which forms the basis for the Governing Council's policy decisions. It is published eight times a year, two weeks after each monetary policy meeting. Moreover, the Eurosystem's consolidated weekly financial statement provides information on monetary policy operations, foreign exchange operations and investment activities. In terms of transparency, it should be noted that Executive Board Members as well as the Chair of the Supervisory Board are publishing their diaries. They cover all professional meetings with the private and public sectors. Finally, any citizen of the EU, and any natural or legal person residing or having its registered office in a Member State, has a right of access to ECB documents, subject to the conditions and limits defined in the ECB's Decision on public access to European Central Bank documents.

These practices are meant to ensure that the ecb provides the general public and the markets with all relevant information on its strategy, assessments and policy decisions as well as its procedures in an open, clear and timely manner. They have evolved over the years and it can be expected that they will further evolve in line with the expectations of the general public, their elected representatives and as part of the interaction with other stakeholders such as the CJEU or the European Ombudsman.

\section{The ECB'S accountability in a political economy perspective}

The ECB's accountability is embedded not only in the legal frame- 
work presented in section 1, but also in a network of interactions with relevant stakeholders. It is in fact useful to think about central bank accountability through the lenses of a principal-agent model 29 . The central bank is indeed delegated certain tasks, which requires safeguards ensuring that central bank officials have the incentives to abide by the mandate they are given. In other words, the central bank is an agent for a principal, who is ultimately the people in a democracy.

In such a principal-agent relationship, a number of issues arise: how can objectives be well-specified? How can the principal effectively monitor the action of the agent given the asymmetry of information? How can incentives be properly designed for the agent to respect the mandate it was given?

The principal-agent theory emphasises notably the importance of contract design. For central banks, this boils down to the mandate it is given and the legal framework applying to it. In particular, a central bank's objectives form the basis for its accountability. In the case of the ECB, the mandate was democratically conferred upon the ECB and is enshrined in primary law ${ }^{30}$. This ensures that this mandate has strong legitimacy, legal force and stability. At the same time, it also means that it is more difficult for the legislator to change it, should it for instance feels the need to specify it more and reduce the discretion of the central bank. There is therefore a trade-off.

Another issue in that context has to do with the definition of the objective. In the case of the $\mathrm{ECB}$, the Treaties give clear priority to the objective of price stability, which was debated during the crisis, as some recommended a dual mandate similar to the FED, while other suggested to make financial stability an objective on the same level as price stability. Moreover, the interpretation of this mandate can be a controversial matter. The Treaties indeed do not give a precise definition of what is meant by price stability. The ECB's Governing Council clarified in 2003 that in the pursuit of price stability it aims to maintain inflation

visory Mechanism (SSM), accessible at: https://www.ecb.europa.eu/ecb/legal/pdf/mou_ between_eucouncil_ecb.pdf

${ }^{29}$ M. FratianNi, J. von Hagen, C. Waller, Central banking as a political principal-agent problem, in "Economic Inquiry", n. 2, 1997, pp. 378-393; M.G.B.EGGERTSSON, M.E. LE BORGNE, A political agency theory of central bank independence, in "Journal of Money, Credit and Banking", n. 4, 2010, pp. 647-677.

${ }^{30}$ For a longer discussion on the ECB, see R. ElGIE, The politics of the European Cen- 
rates below, but close to, $2 \%$ over the medium term. The crisis however spurred controversy about this definition, with some considering that the inflation objective should be lower, others higher, and some considering that the horizon ("medium term") was not sufficiently specified. In response, the ECB sought to further explain the rationale for the definition of price stability it has adopted ${ }^{31}$. Whatever the view one may take on the objective and its definition, clarity and stability are important for the ECB's accountability. They indeed provide a measurable yardstick against which the ЕCB can be held accountable and make monetary policy more transparent and predictable. Changing the objective could on the contrary be perceived as moving the goalposts.

The principal-agent literature also suggests that monitoring of the agent by the principal may prove difficult. In the ECB's case, the inflation rate is published on a monthly basis and can therefore be monitored easily. At the same time, given the medium term horizon of monetary policy and the uncertainty surrounding forecasts, monitoring requires ex ante an assessment of the likelihood that the announced monetary policy decisions will allow to reach the objective, and ex post taking into account the conditions that prevailed when decisions were taken and possible surprises that followed. This requires on the one hand clear explanation by the ECB of the rationale for its decisions and on the other hand the ability for the principal to form a judgement informed by an in-depth understanding of economic and monetary conditions. As explained in section 1, the ECB's accountability framework and practices do ensure that the ECB provides thorough explanations of its decisions. And the European Parliament does form a judgement on the ECB's measures. This judgement is informed in variety of ways. The Economic and Monetary Affairs Committee conducts regular hearings and asks oral and written questions, allowing its members to ask for additional information or challenge ECB's decisions. The Committee is supported by a dedicated secretariat including members with central

tral Bank: principal-agent theory and the democratic deficit, in "Journal of European Public Policy", n. 2, 2002, pp. 186-200.

${ }^{31}$ See for instance the ECB's Feedback on the input provided by the European Parliament as part of its resolution on the ECB Annual Report 2014, available at https://www.ecb.europa.eu/pub/pdf/other/20160407_feedback_on_the_input_provided_by_the_european_parliament_en.pdf?eb392b6d05be9710184f $\mathrm{fa} 0 \overline{5} 16 \mathrm{f} \overline{\mathrm{d}} \mathrm{d} 3 \mathrm{ce} 8$ 
banking experience, as well as by experts who prepare papers on technical and policy issues related to the ECB in advance of regular hearings. Moreover, the Committee appoints each year a rapporteur, along with shadow rapporteurs ensuring all political groups are involved, who prepare the European Parliament's resolution on the ECB.

Finally, it is essential that the agent - the ECB in this case - has the right incentives to act in accordance with the mandate conferred upon it by the principal. Traditional incentives - such as employment contracts and financial incentives - would however collide with the ECB's independence. The ECB's Statute in particular provides for personal independence. As a result, Article 11.4 of the ЕСB Statute only foresees that "if a member of the Executive Board no longer fulfils the conditions required for the performance of his duties or if he has been guilty of serious misconduct, the Court of Justice may, on application by the Governing Council or the Executive Board, compulsorily retire him." Moreover, ECB's Executive Board members have non-renewable single terms, so that the threat of not being reappointed cannot be used to influence them. In addition, the ЕСB has its own financial resources and income and the Statute allows the ECB to organise its internal structure as it sees fit.

The incentives for the ECB to abide by its mandate are therefore of a different nature. They are based on the institutional framework in which the ЕСB is embedded and on the interaction between various institutions. In particular, several other institutions play an important role alongside the European Parliament:

- The CJEU, before which ECB acts can be challenged.

- The European Ombudsman, which can be seized in matters involving the $\mathrm{ECB}$, for instance regarding transparency and good governance.

- The European Court of Auditors, which examines the operational efficiency of the management of the $\mathrm{ECB}^{32}$.

While these institutions are independent, their role interacts with that of the European Parliament. For instance MEPs may seize the European Ombudsman ${ }^{33}$. The reports of the European Court of Auditors

32 See Article 27 of the ECB Statute.

33 An example is the complaint lodged by MEP GIEGOLD on 27 October 2015 concerning the organisation of preparatory measures for the collection of granular credit data by the European System of Central Banks (complaint 1693/2015/PD). 
are also discussed in the European Parliament. Conversely, the judgement of the CJEU in the OMT was emphasised by President Draghi in the European Parliament, where concerns had been expressed on this matter ${ }^{34}$.

\section{The evolution of the ECB's accountability practice during the crisis}

The prominence of the ECB's role during the crisis and its enhanced tasks have inevitably been accompanied by increased controversy around the ECB's decisions, often for contradictory reasons. Some complained that the ЕСв has acted "too little too late", while others have criticized the ЕСB for going too far with its non-standard measures.

Against this background, the intensity of the ECB's interaction with the European Parliament increased, both quantitatively and qualitatively.

First, the number of interactions increased substantially since the start of the crisis. In addition to the regular ECON hearings, the ECB participated in a number of additional exchanges of views at key junctures of the euro area crisis. These included an extraordinary ECON hearing of the President in August 2011 on the financial and economic crisis, as well as an in-camera exchange of views on the report "Towards a genuine Economic and Monetary Union" with the President in 2012. Furthermore, there were three additional ECON hearings on economic matters, one exchange of views on the crisis in general, as well as two more on economic governance and four exchanges of views on payment and settlement system issues. Finally, Executive Board Members participated in several inter-parliamentary meetings involving also members of national parliaments ${ }^{35}$. A number of ECB staff also participated in public hearings on topical issues.

${ }^{34}$ Hearing of the Committee on Economic and Monetary Affairs of the European Parliament, Introductory statement by Mario DRAGHI, President of the ECB, Brussels, 21 June 2016.

35 While the ECB is not accountable to National Parliaments, it is worth noting that since 2012, the ECB President spoke before five national parliaments: in Germany (in 2012 and 2016), in Spain and France (2013), in Finland (2014), in Italy (2015) in the Netherlands (2017). Moreover, other Members of the Executive Board also participated to meetings in National Parliaments in France and Germany. 
Appearances in the EP were complemented by other forms of interactions, which also became more frequent: in particular, the number of MEPS' written questions to the ЕСB has considerably increased since the start of the sovereign debt crisis. More than twice as many written questions were sent over 2009-2014 (i.e. 146 written questions) compared to 2005-2009 (i.e. 62 written questions). While in 2008 only 11 written questions were received by the ECB, in 2013 this number had already reached 55. In the current parliamentary term so far, between 2014 and March 2017, some 383 letters have already been received, of which 317 addressed to the President of the ecb and 66 to the Chair of the Supervisory Board.

Against this rising trend of interactions between the ECB and EP, it is worth zooming on two specific instances. The first one is the case of ECB's involvement in macroeconomic adjustment programmes. Since 2010, there were three additional ECON hearings on this matter ${ }^{36}$. The high political salience of the new role performed by the ECB as part of the Troika could also be traced in the fact that around $20 \%$ of the written questions since 2009 related to the economic situation in stressed countries and the work of the Troika. Finally, the ECB also provided replies to a questionnaire of the European Parliament supporting the own initiative report evaluating the structure, the role and operations of the Troika in euro area programme countries ${ }^{37}$.

A second example relates to the exchanges between the ecb and the European Parliament in relation to a statistical project (AnaCredit) to set up a dataset containing detailed information on individual bank loans in the euro area, harmonised across all Member States ${ }^{38}$. The principle of independence granted to the ECB also covers the possibility of adopting statistical Regulations for collecting data needed for its policy

36 J. ASMUSSEN participated twice in exchanges of views on the topic: First, in 2012 in a public exchange of views on the economic and social crisis in Greece with the members of ECON and the Committee on Employment and Social Affairs; then in 2013, alongside Commissioner Rehn to give the ECB's assessment of the situation in Cyprus in 2013. Finally, BENOÎT CEeURÉ participated in an exchange of views on the ECB'S role in EU-IMF macroeconomic adjustment programmes on 13 February 2014.

${ }^{37}$ See https://www.ecb.europa.eu/pub/pdf/other/140110_ecb_response_troika_questionnaireen.pdf

38 The ЕСв launched the project in 2011 - together with the euro area and some noneuro area national central banks. 
making. This process is conducted in full autonomy, but data are compiled following the statistical principles developed by the EU legislators. Among the other things, in line with the principle of minimisation of the reporting burden, the ЕСВ has, since 2000, regularly been conducting merits and costs procedures as part of its impact assessment, which it carries out for all new regulations on European statistics. This process attracted the attention of several Members of the European Parliament in relation to the AnaCredit project. Some written questions were sent in relation to it ${ }^{39}$ and some members also raised the issue in regular hearings of the President and of the Chair of the Supervisory Board. The ECB reacted to this increasing interest, not only answering questions in the regular fora, but also engaging by engaging in further interactions in ECON. Two ad-hoc meetings were organised to specifically discuss the issue, at technical and Executive Board member level ${ }^{40}$. Moreover, to enhance the transparency of the process (which was criticised by some MEPS), the ECB decided that in future the impact assessment for draft new ECB regulations on European statistics would be complemented by public consultations these draft ECB regulations. The Governing Council will decide on the final regulations after the end of the relevant public consultation ${ }^{41}$.

\section{Conclusions}

Consistent with the decisive role it has played in the crisis, the ECB has come under increased scrutiny. The pre-existing accountability framework has allowed for such increased scrutiny and therefore showed its robustness. What has changed is indeed not the accountability framework foreseen in primary law, but the extended use of its possibilities. And the evidence shows that the ECB compares favourably among central banks. The accountability of the ECB will however continue to be the subject of debate given the various possible equilibria concerning the role of the various stakeholders, the intensity of scrutiny

\footnotetext{
${ }^{39}$ See https://www.ecb.europa.eu/pub/pubbydate/2015/html/index.en.html?skey $=$ Letter\%20AnaCredit

${ }^{40} \mathrm{See}$ https://www.ecb.europa.eu/press/key/date/2016/html/sp160125.en.html

${ }^{41} \mathrm{See}$ https://www.ecb.europa.eu/press/govcdec/otherdec/2016/html/gc161021.en.html
} 
and the interaction between various accountability channels. These are all fundamental factors in ensuring high quality interactions in the discharge of the ECB's accountability obligations.

It can also be expected that the practice of the ECB accountability will continue to further evolve, as the use of the various channels of accountability is further developed. Relations with citizens' elected representatives, ECB's communication and transparency, and interactions with other institutions such as the CJEU, the ECA and the European Ombudsman, will continue to reflect the constant need for the ecb to demonstrate that it is acting in accordance with the democratic mandate it received, as a fundamental pillar of its legitimacy.

Some observers have considered that the ECB's accountability framework may be amended in various ways ${ }^{42}$. This debate is useful as it may allow to further improve the ECB's accountability. However, it is also important to acknowledge when such suggestions imply potential trade-offs, in particular with the principle of independence, for instance as regards including the details of who voted what in the accounts of the ECB's monetary policy meetings. Some suggestions may also risk blurring the lines: for instance, Transparency International considered that there should be "political approval procedures for measures that go beyond [the ECB's] mandate but could help avert or contain a crisis"43. It would however seem preferable that measures falling outside the ECB's mandate and requiring political approval are decided and implemented by other institutions, including new institutions where a gap is identified in EMU's governance as was the case with the creation of the European Stability Mechanism.

Trust in the central banks moreover depends on more than just strong accountability. Trust in the ECB also depends on factors such as support for the currency, trust in public institutions more broadly (given the institutional system in which the ECB is embedded), economic performance (given the role of output legitimacy) and convergence within the euro area (which increases the effectiveness of monetary policy).

\footnotetext{
42 For instance, Transparency International proposed to give the EP, via the ECON Committee, confirmation power in the appointment process for Executive Board members.

43 Transparency International, Two sides of the same coin? Independence and Accountability of the European Central Bank (2017) Available at: https://transparency.eu/ wp-content/uploads/2017/03/TI-EU_ecb_Report_DIGITAL.pdf
} 
In this respect, the ЕСв has a genuine interest in a well-functioning and trusted Economic and Monetary Union.

Ten years after the start of the Great Recession, the recovery is under way in the euro area. Deflation risks have disappeared, inflation is gradually returning towards the ECB's objective, unemployment is steadily decreasing, growth is solid and its dispersion across euro area countries and sectors has declined sharply. Not only can the ECB claim it has acted during the crisis in line with its mandate, but there is tangible evidence that it has played in the process a central role in overcoming an existential crisis for the euro area and in supporting the recovery.

Nevertheless, controversies have not disappeared. Unconventional monetary policies, the role of the ECB in stemming risks to financial stability, or the ECB's role in the Troika continue to be debated. Moreover, the widespread erosion of trust towards public institutions suggests even broader implications that go beyond the changes in the ECB's accountability framework and that would warrant further analysis. For instance, in view of the gap between the European citizens and European institutions, including the ECB and the EP, there may be a need for strengthening the outreach effort. Moreover, just like the ECB's central role in the crisis had to be matched by strong accountability, all European institutions need accountability frameworks and practices commensurate to their powers to support their legitimacy. In this respect, any further deepening of EMU will need as one of its component the establishment of commensurate accountability provisions.

\section{Further Bibliography}

S. BINDER, M. SPINDEL, Independence and accountability: Congress and the Fed in a polarized era, Brookings Governance Studies, 2016, Available at: https://www.brookings.edu/wp-content/uploads/ 2016/07/Monetary-politics.pdf 
Riassunto - L'accountability della BCE comprende i vari canali attraverso i quali essa è chiamata a dimostrare di agire in conformità con il suo mandato. Il presente articolo si concentra principalmente su uno di questi canali la responsabilità democratica. È tuttavia importante tenere presente che questi diversi canali si rafforzano a vicenda. Inoltre, nel discutere il quadro di responsabilità della BCE, l'attenzione principale è rivolta alle funzioni di banca centrale, piuttosto che di vigilanza. Coerentemente con il ruolo decisivo che ha svolto nella crisi, la BCE è stata sottoposta a un maggiore controllo. Il quadro di responsabilità preesistente ha consentito tale maggiore controllo e ha quindi dimostrato la sua solidità. Ciò che è cambiato, in effetti, non è il quadro di responsabilità previsto dal diritto primario, ma l'uso esteso delle sue possibilità. E l'evidenza dimostra che la BCE si confronta favorevolmente con le banche centrali. La responsabilità della $\mathrm{BCE}$ continuerà comunque ad essere oggetto di dibattito, visti i vari equilibri possibili sul ruolo dei vari stakeholder, l'intensità del controllo e l'interazione tra i vari canali di responsabilità. Tutti fattori fondamentali per garantire un'interazione di alta qualità nell'adempimento degli obblighi di responsabilità della BCE. 